An Illustrated Manual of Pacific Coast Trees By Prof. Howard E. McMinn and Evelyn Maino. With List of Trees recommended for various uses on the Pacific Coast, by Prof. H. W. Shepherd. Pp. xii +409 . (Berkeley, Calif. : University of California Press ; London: Cambridge University Press, 1935.) 16s. net.

OF the numerous works dealing with trees and shrubs, there are few of pocket size which cater specially for the needs of the amateur botanist and garden enthusiast. Prof. McMinn's small manual is to be welcomed accordingly. Though intended primarily for use on the pacific seaboard of North Amorica from British Columbia southward, the inclusion of a large number of cultivated trees will extend its sphere of usefulness. It will not, however, be of special value in Great Britain.

Artificial keys are used for distinguishing both genera and species. The generic key makes almost exclusive use of vegetative characters, and is simple and easy to use. Characters of the reproductive parts are employed more often for identifying the species. The keys are generally accurate, but ex. ception must be taken to the separation of the English elm from the slippery elm by the presence of corky wings on the branches. It is curious indeed if the somewhat rare corky-barked variety of the British Ulmus procera Salisb. should be the common type in cultivation west of the Rockies. The am. biguous name $U$. campestris $\mathrm{L}$. is adopted for this species, with $U$. procera Salisb. bracketed as a synonym. A number of similar errors are caused by following the list of "Standardised Plant Names" of the American Joint Committee on Horticultural Nomenclature. To the fault of the same authority is due the decapitalization without exception of all specific names.

The book is liberally illustrated with original line drawings of leaves, fruits and flowers, which supple. ment the short descriptions in the text. The marginal veinlets are frequently drawn in the leaves with great care, although no use is made of vein characters for diagnosis. A further interesting feature is an appendix of twenty-nine pages. This gives lists of trees suitable for particular purposes and adapted for growth in a variety of soil types from dune sand to alkali soils.

\section{Les races humaines}

Par P. Lester et Prof. J. Millot. (Collection Armand Colin: Section de biologie, No. 192.) Pp. 223. (Paris : Armand Colin, 1936.) 10.50 francs.

REPERCUSSIONS of political events have brought about a general stocktaking in racial studies, of which the most important result has been that it has constrained anthropologists to clarify and restate their views on the definition of race, the essential qualities, or characters, on which racial classification is based, and on the classification of existing races. Numerous manuals have appeared with the object of removing misapprehensions among the general public as to the character and implications of the term, when used in the strict and only sense which can be regarded as applicable to Homo sapiens according to his physical characters.

Among such manuals a high place can be assigned to "Les Races Humaines" by MM. Lester and Millot. It is eminently sane and well-balanced; and it has the advantage for the layman that it does not confine itself to anatomical characters. By its treatment of the racial aspect of physiological studies, in such matters as growth, the blood-groups, metabolism, the nervous system and a number of related subjects of investigation, it indicates that racial studies cover an extremely wide and varied group of phenomena, which, as yet, affords little ground for confident generalization.

Here the view of the authors, put briefly, is that 'race' is not stable, and that as a basis of classification of the varieties of man, it has, so far as our present knowledge goes, little more than methodological validity.

\section{Textbook of Quantitative Analysis}

By Prof. William Thomas Hall. Second edition. Pp. ix +350. (New York: John Wiley and Sons, Ine.; London: Chapman and Hall, Ltd., 1935.) 15s. net.

Prof. HALL's book, which is divided into two parts, provides a course of elementary quantitative analysis and a course of analyses of technical products corresponding with works laboratory practice. In both parts it is marked by careful description and emphasis on points which usually give trouble to students. A large amount of very sensible practical advice is given without running into the fault of some American practical books of labouring the obvious.

The theory is equally satisfactory; as examples, the discussions on $p \mathrm{H}$ values and indicators, on oxidation and reduction, and on the theory of electrolytic separations may be mentioned. The descriptions of the manipulations give all the neces. sary details, so that the student using the book should be able to make good progress without too much personal attention from the demonstrator. The reasonable price of the book is deserving of mention.

\section{Distillation}

By Prof. Joseph Reilly. (Methuen's Monographs on Chemical Subjects.) Pp. viii +120 . (London : Methuen and Co., Ltd., 1936.) 3s. 6d. net.

THE book under notice contains a mathematical account of the theory of distillation, the theory of frac. tionating columns, and a discussion of the apparatus and methods involved in distillation, both laboratory and industrial. The section on low-pressure distillation is of particular interest, since some modern industrial processes, such as the purification of vitamins, depend upon this process. The separation of liquids by the principle of azeotropic mixtures is dealt with fairly fully, especially as it concerns the dehydration of alcohol, which is becoming important with the use of 99-100 per cent alcohol for motor fuel.

There are also sections on destructive distillation and on sublimation. The book is well illustrated and gives a competent survey of the modern processes of distillation. 